University of Nebraska - Lincoln

DigitalCommons@University of Nebraska - Lincoln

Agronomy \& Horticulture -- Faculty Publications

Agronomy and Horticulture Department

2009

\title{
High-Yielding Corn Response to Applied Phosphorus, Potassium, and Sulfur in Nebraska
}

\author{
Charles S. Wortmann \\ University of Nebraska-Lincoln, cwortmann2@unl.edu \\ Achim R. Dobermann \\ University of Nebraska-Lincoln, adobermann2@unl.edu \\ Richard B. Ferguson \\ University of Nebraska-Lincoln, rferguson1@unl.edu \\ Gary W. Hergert \\ University of Nebraska-Lincoln, ghergert1@unl.edu \\ Charles A. Shapiro \\ University of Nebraska-Lincoln, cshapiro1@unl.edu
}

See next page for additional authors

Follow this and additional works at: https://digitalcommons.unl.edu/agronomyfacpub

Part of the Plant Sciences Commons

Wortmann, Charles S.; Dobermann, Achim R.; Ferguson, Richard B.; Hergert, Gary W.; Shapiro, Charles A.; Tarkalson, D. D.; and Walters, Daniel T., "High-Yielding Corn Response to Applied Phosphorus, Potassium, and Sulfur in Nebraska" (2009). Agronomy \& Horticulture -- Faculty Publications. 327.

https://digitalcommons.unl.edu/agronomyfacpub/327

This Article is brought to you for free and open access by the Agronomy and Horticulture Department at DigitalCommons@University of Nebraska - Lincoln. It has been accepted for inclusion in Agronomy \& Horticulture -Faculty Publications by an authorized administrator of DigitalCommons@University of Nebraska - Lincoln. 


\section{Authors}

Charles S. Wortmann, Achim R. Dobermann, Richard B. Ferguson, Gary W. Hergert, Charles A. Shapiro, D. D. Tarkalson, and Daniel T. Walters 


\title{
High-Yielding Corn Response to Applied Phosphorus, Potassium, and Sulfur in Nebraska
}

\author{
C. S. Wortmann,* A. R. Dobermann, R. B. Ferguson, \\ G. W. Hergert, C. A. Shapiro, D. D. Tarkalson, and D. T. Walters
}

\begin{abstract}
Nutrient management recommendations may change as yield levels and efficiency of crop production increase. Recommendations for $\mathrm{P}, \mathrm{K}$, and $\mathrm{S}$ were evaluated using results from 34 irrigated corn (Zea mays $\mathrm{L}$.) trials conducted in diverse situations across Nebraska. The mean yield was $14.7 \mathrm{Mg} \mathrm{ha}^{-1}$ with adequate fertilizer applied. The median harvest index values were $0.52,0.89$, 0.15 , and 0.56 for biomass, $\mathrm{P}, \mathrm{K}$, and $\mathrm{S}$, respectively. Median grain yields were 372,49 , and $613 \mathrm{~kg} \mathrm{~kg}^{-1}$ of aboveground plant uptake of $\mathrm{P}, \mathrm{K}$, and $\mathrm{S}$, respectively. The estimated critical Bray-1 P level for corn response to $20 \mathrm{~kg} \mathrm{P} \mathrm{ha}^{-1}$ was $20 \mathrm{mg} \mathrm{kg}^{-1}$ when the previous crop was corn compared with $10 \mathrm{mg} \mathrm{kg}^{-1}$ when corn followed soybean [Glycine max (L.) Merr.]. Soil test $\mathrm{K}$ was generally high with only three site-years $<125 \mathrm{mg} \mathrm{kg}^{-1}$. Over all trials, application of $40 \mathrm{~kg} \mathrm{~K} \mathrm{ha}^{-1}$ resulted in a $0.2 \mathrm{Mg} \mathrm{ha}^{-1}$ mean grain yield decrease. Application of $22 \mathrm{~kg} \mathrm{Sha}^{-1}$ did not result in significant yield increase in any trial. Soil test results accounted for twice as much variation in nutrient uptake when soil organic matter (SOM) and $\mathrm{pH}$ were considered in addition to the soil test nutrient values. The results indicate a need to revise the current recommendation for $P$, to maintain the current $K$ and $S$ recommendations, and to use SOM and $\mathrm{pH}$ in addition to soil test nutrient values in estimating applied nutrient requirements for irrigated high yield corn production.
\end{abstract}

$\mathrm{O}$ N-GOING IMPROVEMENT of nutrient recommendations for crops is necessary because of changes in yield levels, varieties and production practices, and economic conditions. In the western Corn Belt and Great Plains of the United States, many land-grant universities including the University of Nebraska-Lincoln (UN-L) have utilized the deficiency correction approach to making nutrient recommendations. Soil tests are used with other production information to recommend nutrient application based on the probability of economic response.

The basis for calibration of the Bray-1 P and Olsen P soil tests was published by Olson et al. (1954), with further refinement of the interpretation of soil test results using later research results including different rates for broadcast and band application (Shapiro et al., 2003). Current UN-L recommendations do not recommend $\mathrm{P}$ and $\mathrm{K}$ application for corn when Bray-1 $P$ is greater than $15 \mathrm{mg} \mathrm{kg}^{-1}$ and exchangeable $\mathrm{K}$ is greater than $124 \mathrm{mg} \mathrm{kg}^{-1}$, respectively. Recommended $\mathrm{S}$ application is limited to sandy soils with less than $10 \mathrm{mg} \mathrm{kg}^{-1} \mathrm{SOM}$ and $<8$ $\mathrm{mg} \mathrm{kg}^{-1} \mathrm{SO}_{4}-\mathrm{S}$ by $\mathrm{Ca}\left(\mathrm{H}_{2} \mathrm{PO}_{4}\right)_{2}$ extraction.

In studies conducted more than $20 \mathrm{yr}$ ago, the UN-L recommendations for corn were found to be more profitable with less

C.S. Wortmann, R.B. Ferguson, G.W. Hergert, C.A. Shapiro, and D.T. Walters, Agronomy and Horticulture Dep., Univ. of Nebraska, Lincoln, NE; A. Dobermann, IRRI; D.D. Tarkalson, USDA-ARS. Contribution of the University of Nebraska-Lincoln Agricultural Research Division. This research was partly funded by the Hatch Act and the Nebraska State Legislature. Received 19 Sep.2008. ${ }^{*}$ Corresponding author (cwortmann2@unl.edu).

Published in Agron. J. 101:546-555 (2009).

doi:10.2134/agronj2008.0103x

Copyright (C) 2009 by the American Society of Agronomy, 677 South Segoe Road, Madison, WI 53711. All rights reserved. No part of this periodical may be reproduced or transmitted in any form or by any means, electronic or mechanical, including photocopying, recording, or any information storage and retrieval system, without permission in writing from the publisher.

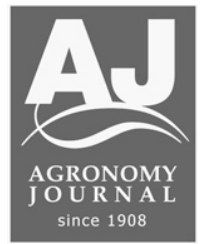

$\mathrm{P}, \mathrm{K}$, and $\mathrm{S}$ applied compared with recommendations based on nutrient replenishment or other approaches (Olson et al., 1982, 1987; McCallister et al., 1987). These results verified the UN-L P recommendations and there were no yield responses to applied $\mathrm{K}$.

Soil test calibration may be needed for high yield situations and current cropping and tillage systems. Current $\mathrm{P}$ and $\mathrm{K}$ recommendations were mainly based on research conducted when mean corn grain yields in Nebraska were less than $5 \mathrm{Mg} \mathrm{ha}^{-1}$ compared with the 2008 average of more than $10 \mathrm{Mg} \mathrm{ha}^{-1}$ (USDA-NASS, 2008) and with yields often exceeding $15 \mathrm{Mg} \mathrm{ha}^{-1}$. More recent research conducted in Iowa supports the current UN-L recommendations, although $\mathrm{P}$ application when Bray-1 P is between 15 and $20 \mathrm{mg} \mathrm{kg}^{-1}$ could be economical when the P fertilizer/corn price ratio is relatively low (Mallarino and Blackmer, 1992; Webb et al., 1992). Results from 26 no-till trials conducted in Iowa support the UN-L P recommendation for corn; yield of corn following soybean in rotation was increased by $\mathrm{P}$ application in starter fertilizer for 8 of 11 cases where Bray-1 P was less than $12 \mathrm{mg} \mathrm{kg}^{-1}$, but in no cases where Bray-1 P was greater than $12 \mathrm{mg} \mathrm{kg}^{-1}$ (Bordoli and Mallarino, 1998). Corn yields ranged from 5.4 to $12.9 \mathrm{Mg} \mathrm{ha}^{-1}$. In another study in Iowa, however, critical Bray-1 P levels were determined to be between 15 and $21 \mathrm{mg} \mathrm{kg}^{-1}$ for corn (Dodd and Mallarino, 2005). The response was similar for $14 \mathrm{~kg} \mathrm{P} \mathrm{ha}^{-1}$ as for higher rates. Research has been conducted in Nebraska on P placement (Sleight et al., 1984; Raun et al., 1987; Rehm et al., 1988; Eghball and Sander, 1989a, 1989b; Eghball et al., 1990) that led to differing rates with broadcast compared with band application.
Abbreviations: GY, grain yield; HI, harvest index; IE, internal efficiency or grain produced per unit of nutrient in aboveground biomass; RIE, reciprocal of IE, or nutrient uptake require per unit of grain; SOM, soil organic matter; UNL, University of Nebraska-Lincoln; UP, total phosphorus uptake in the aboveground biomass; UK, total potassium uptake in the aboveground biomass; US, total sulfur uptake in the aboveground biomass. 
Illite is a major $\mathrm{K}$ source in Nebraska soils, including coarse-textured soils (Fawzi and Drew, 1966). Significant yield responses to applied $\mathrm{K}$ did not occur on sandy soils in northeastern Nebraska where exchangeable K was below the critical level of $125 \mathrm{mg} \mathrm{kg}$ (Rehm et al., 1981, 1983; Rehm and Sorensen, 1985). On irrigated and nonirrigated Mollisol soils testing high in $\mathrm{K}$, there was often a yield depression at the highest $\mathrm{K}$ rate (McCallister et al., 1987). The current UN-L recommendation is supported by the findings of Mallarino and Blackmer (1994), who determined the critical soil $\mathrm{K}$ value for profit maximization to be $112 \mathrm{mg} \mathrm{kg}^{-1}$ by ammonium acetate extraction or $70 \mathrm{mg} \mathrm{kg}^{-1}$ by Mehlich III extraction. They estimated the rate of $\mathrm{K}$ release at these soil test $\mathrm{K}$ levels to be $1.0 \mathrm{~kg} \mathrm{ha}^{-1} \mathrm{~d}^{-1}$.

Fertilizer S recommendations for Nebraska soils were based on research by Rehm $(1978,1984,1993)$, and consider primarily soil texture and SOM (Rehm, 2000). Calcium-phosphate extracted S (Fox et al., 1964) was considered in sandy soils with low SOM in the current UN-L recommendation. There was no corn grain yield response to $S$ in starter fertilizer in 12 trials conducted on medium and fine-texture soil in eastern Nebraska (Wortmann et al., 2006a).

Olson et al. (1958) found a close correlation between soil test $\mathrm{P}$ and $\mathrm{K}$ in the 0 - to $20-\mathrm{cm}$ and 20 to $50-\mathrm{cm}$ soil depths and soil tests were calibrated for the 0 - to $20-\mathrm{cm}$ depth. More than 40 additional years of intensive crop production may have affected nutrient distribution in the soil profile and may imply a need for differing soil sampling procedures. Nutrient stratification develops with no-till, especially for P (Garcia et al., 2007), but recommendations based on sampling the 0 - to 20-cm depth may still be most appropriate for no-till and tilled fields (Mallarino and Borges, 2006).

Interpretation of soil test results for estimation of soil capacity to supply nutrients to a crop might be improved by considering soil $\mathrm{pH}$ and SOM together with soil nutrient level (Janssen et al., 1990). The capacity of soil, together with decomposing plant residues, to supply nutrients is equal to or greater than crop nutrient uptake with no nutrients applied and the capacity of nutrient supply can be related to estimated crop nutrient uptake to achieve expected yields. Grain yield per unit of nutrient uptake, or the internal efficiency of nutrient use (IE) (Witt et al., 1999), may vary with level of nutrient availability, production systems, hybrids, and various other abiotic and biotic factors. Therefore, IE can range from maximum nutrient accumulation to maximum nutrient dilution for yield per unit of nutrient uptake.

The objectives of this research were to: (i) compare soil test $\mathrm{P}$ sampling and analytical procedures; (ii) improve estimation of soil nutrient supply capacity and crop nutrient uptake; and (iii) verify or fine-tune fertilizer $\mathrm{P}, \mathrm{K}$, and $\mathrm{S}$ recommendations for high yield corn production across the major corn production agroecological zones and crop rotations.

\section{MATERIALS AND METHODS}

Nutrient response trials were conducted from 2002 to 2004 for 34 site-years with 11 to 12 trials conducted each year across Nebraska, including most major irrigated corn areas (Table 1). Of the 34 site-years, 13 and 21 were on research stations and producers' fields, respectively. Nine, 11 , and 14 trials were conducted with ridge-till, no-till, and conventional tillage consisting of disk or chisel plow tillage, respectively. Corn followed corn, soybean, and dry bean (Phaseolus vulgaris L.) in 16, 13 , and 5 site-years, respectively, with the dry bean production in western Nebraska. The elevation range was from 370 to 1190 $\mathrm{m}$ above sea level and the latitude from approximately 40.1 to $42.4^{\circ} \mathrm{N}$. Soil properties ranged widely as addressed below and in Table 1. Only the Paxton 2002 and 2003 trials were repeated on the same field site. Therefore, the results are widely applicable to high yield corn production in temperate areas of similar daylength.

Eleven site-years had either loamy sand or sandy loam soil and the remaining had either silt loam or silty clay loam soil (Table 1). Soil samples of the 0 - to 20 -cm depth were analyzed according to the Missouri Agricultural Experiment Station (1998). Soil organic matter ranged from 7 to $34 \mathrm{mg} \mathrm{kg}^{-1}$ with a median of $25.5 \mathrm{mg} \mathrm{kg}^{-1}$. Initial soil fertility characteristics varied widely among the sites. About $40 \%$ of the sites had soil test P levels below the current critical level of $15 \mathrm{mg} \mathrm{kg}^{-1}$ Bray-1 $\mathrm{P}$, but soil test $\mathrm{K}$ was below the current critical level of $125 \mathrm{mg}$ $\mathrm{kg}^{-1}$ at just two sites. None of the sites were below the critical level in both $\mathrm{P}$ and $\mathrm{K}$.

The treatment combinations included $\mathrm{P}$ applied at 0,20 , and $40 \mathrm{~kg} \mathrm{ha}^{-1}$ and $\mathrm{K}$ applied at 0,40 , and $80 \mathrm{~kg} \mathrm{ha}^{-1}$ (Table 1). In addition, one or two $S$-applied treatments were included in five site-years with medium or fine-texture soil and four site-years with sandy soil at rates of 0 and $20 \mathrm{~kg} \mathrm{ha}^{-1}$. All trials also included treatments for evaluation of crop response to four $\mathrm{N}$ rates but these results are not addressed in this article. The $\mathrm{N}$ rates were constant within trials for testing the effects of $\mathrm{P}$, $\mathrm{K}$, and $\mathrm{S}$ rates. Fertilizer $\mathrm{P}$ and $\mathrm{K}$ were broadcast-applied at or shortly before planting as triple super phosphate and potassium chloride, respectively, and incorporated at the conventional tillage sites. Sulfur was broadcast-applied as gypsum.

The experimental design was a randomized complete block with four replications. The minimum plot size was six rows $\left(0.76 \mathrm{~m} \mathrm{row}^{-1}\right)$ by $15 \mathrm{~m}$, but plot width was often wider depending on planting equipment.

The cooperating farmer chose the hybrid and weed control practices. Nitrogen was applied in split applications of $60 \%$ preplant and $40 \%$ at the V6 stage for medium or fine-texture soils, and $40 \%$ preplant and $30 \%$ each at the V6 and V10 stages for sandy soils (Table 1). Sulfur was applied to all plots for a few trials with sandy soil. Soil tests did not indicate a need for $\mathrm{Zn}$ and other nutrients and these were not applied. The targeted plant density was 7.4 to 8.6 plants $\mathrm{m}^{-2}$. Irrigation was applied to maintain available soil water above $50 \%$ of field capacity at all growth stages to avoid any interference of water deficits with nutrient response. Sites had either center-pivot or furrow irrigation.

\section{Soil Sampling and Measurements}

Soil samples collected for each plot before planting with hand probes were comprised of 10 cores each from the 0 - to $20-\mathrm{cm}$ and the 20 - to $40-\mathrm{cm}$ depths, each centered between crop rows except in ridge-till sites where the soil cores were collected on the ridge shoulder, about $15 \mathrm{~cm}$ from the row. At no-till sites, the first core was split for the 0 - to $10-\mathrm{cm}$ and the $10-\mathrm{cm}$ to $20-\mathrm{cm}$ depths. The samples were analyzed for texture 
Table I.Site-year characteristics, including means and standard deviations for soil test properties, for 34 irrigated corn $\mathbf{N}$ response trials conducted in Nebraska.

\begin{tabular}{|c|c|c|c|c|c|c|c|c|c|c|c|c|c|c|}
\hline & \multirow[b]{2}{*}{ Site-year } & \multirow[b]{2}{*}{ Soilt } & \multirow{2}{*}{\multicolumn{2}{|c|}{ e crop $\begin{array}{c}\text { Previous } \\
\text { crop }\end{array}$}} & \multirow[b]{2}{*}{ Till } & \multirow[b]{2}{*}{ SOM } & \multirow{2}{*}{$\begin{array}{l}\text { Soil } \\
\text { pH }\end{array}$} & \multirow[b]{2}{*}{ Bray-I P } & \multirow{2}{*}{$\begin{array}{c}\text { Olsen } \\
\text { P }\end{array}$} & \multirow{2}{*}{$\begin{array}{c}\text { Soil } \\
\text { K }\end{array}$} & \multicolumn{4}{|c|}{$\mathbf{N}$ rate $\S$} \\
\hline & & & & & & & & & & & P0-20 & P20-40 & $\mathrm{KO}-40$ & K40-48 \\
\hline & & & & & & \multicolumn{2}{|l|}{$\mathrm{mg} g-\mathrm{I}$} & \multicolumn{3}{|c|}{$\longrightarrow \mathrm{mg} \mathrm{kg-l} \longrightarrow$} & \multicolumn{4}{|c|}{$\longrightarrow \mathrm{kg} \mathrm{ha}^{-1} \longrightarrow$} \\
\hline & & & & & & & $\underline{2002}$ & & & & & & & \\
\hline I. & Mead & Tomek & siCL & soybean & NT & $31,1.6$ & $6.2,0.20$ & $13,5.2$ & $8.2,3.7$ & $47 I, 5 I$ & 140 & 280 & 140 & 280 \\
\hline 2. & Wymoreף & Wymore & siCL & soybean & NT & $27,1.4$ & $6.3,0.14$ & $5,0.5$ & $2.8,0.7$ & 376,18 & 140 & 280 & 140 & 280 \\
\hline 3. & Brunswick $\mathbb{T}$ & Thurman & IS & soybean & NT & $7,1.3$ & $6.5,0.14$ & $21,4.2$ & $14.3,3.0$ & 93,16 & 140 & 280 & 140 & 280 \\
\hline 4. & ConcordT & Nora & siL & soybean & NT & $33,2.0$ & $5.8,0.12$ & $\mathrm{II}, 3.0$ & $8.0,2.2$ & 292,73 & 140 & 280 & 140 & 280 \\
\hline 5. & Bellwoodף & Muir & IS & corn & RT & $|4,2|$. & $6.3,0.30$ & $15,3.6$ & $10.0,3.1$ & 106,21 & 181 & 321 & 181 & 321 \\
\hline 6. & Cairo & Hall & siL & corn & RT & $25,2.0$ & 7.I, 0.24 & $13,6.4$ & $10.7,4.8$ & 530,72 & 190 & 336 & 190 & 336 \\
\hline 7. & Clay Center & Hastings & siL & corn & RT & $29,2.1$ & $6.9,0.10$ & $17,10.5$ & $16.4,10.3$ & 516,84 & 190 & 336 & 190 & 336 \\
\hline 8. & SCAL & Crete & siL & soybean & $\mathrm{CT}$ & $30,1.6$ & $6.1,0.24$ & $13,2.4$ & $9.1,2.8$ & 517,69 & 140 & 280 & 140 & 280 \\
\hline 9. & North Platte & Cozad & siL & corn & RT & $21,1.5$ & $7.2,0.16$ & $10,1.6$ & $4.6,1.1$ & 505,64 & 190 & 336 & 190 & 336 \\
\hline 10. & Paxtonף & Vetal & IS & corn & $\mathrm{CT}$ & $14,1.4$ & $6.3,0.27$ & $17,4.6$ & I।.2, 3.7 & 407,123 & 190 & 336 & 190 & 336 \\
\hline II. & Scottsbluff & Mitchell & siL & drybean & $\mathrm{CT}$ & $20,1.7$ & $8.0,0.07$ & $46,8.3$ & $26.5,5.0$ & 604,53 & 190 & 336 & 190 & 336 \\
\hline \multirow[t]{2}{*}{12.} & Box Butte & Creighton & $s L$ & drybean & $\mathrm{CT}$ & $18,1.6$ & $7.0,0.24$ & $74,7.4$ & $40.0,7.4$ & 644,60 & 190 & 336 & 190 & 336 \\
\hline & & & & & & & $\underline{2003}$ & & & & & & & \\
\hline 13. & Mead & Tomek & siL & soybean & NT & $30,1.5$ & $6.4,0.19$ & $10,2.9$ & $5.9,2.2$ & $362,4 I$ & 168 & 280 & 168 & 280 \\
\hline 14. & Pickrell & Wymore & siCL & soybean & NT & $29,1.9$ & $5.8,0.13$ & $11,3.0$ & $7.4,2.4$ & 406,52 & 168 & 280 & 168 & 280 \\
\hline 15. & BrunswickT & Crofton & $\mathrm{siL}$ & soybean & NT & $19,2,1$ & $6.8,0.25$ & $19,5.7$ & $12.2,3.6$ & 329,38 & 168 & 280 & 168 & 280 \\
\hline 16. & ConcordT & Nora & siL & soybean & NT & $30,1.9$ & $5.8,0.28$ & $37,11.3$ & $20.9,5.7$ & 502,68 & 168 & 280 & 168 & 280 \\
\hline 17. & Bellwoodף & Muir & $s L$ & corn & RT & $13,1.6$ & $6.0,0.42$ & $38,10.7$ & 2I.I, 7.1 & 147,32 & 224 & 375 & 224 & 375 \\
\hline 18. & Cairo & Hall & siL & corn & RT & $27,2.3$ & $6.9,0.41$ & $16,7.5$ & II.8, 5.3 & 624,61 & 224 & 336 & 224 & 336 \\
\hline 19. & SCAL & Crete & siL & soybean & CT & $33,2.8$ & $6.6,0.13$ & $23,14.2$ & $13.9,9.6$ & 608,85 & 168 & 280 & 168 & 280 \\
\hline 20. & North Platte & Cozad & siL & corn & RT & $20,2.1$ & $7.3,0.11$ & $12,2.6$ & $5.8,1.2$ & 554,59 & 224 & 336 & 224 & 336 \\
\hline 21. & Paxtonף & Vetal & IS & corn & CT & $13,1.5$ & $6.3,0.24$ & $19,6.0$ & $8.6,4.0$ & 450,47 & 224 & 336 & 224 & 336 \\
\hline 22. & Scottsbluff & Mitchell & siL & drybean & $\mathrm{CT}$ & $16,2.6$ & $7.5,0.15$ & $40,10.5$ & $25.8,8.7$ & 474,59 & 224 & 336 & 224 & 336 \\
\hline \multirow[t]{2}{*}{23.} & Box Butte & Creighton & $s L$ & drybean & CT & $17,1.1$ & $7.3,0.21$ & $22,7.7$ & | I.0,4.| & 491, 39 & 224 & 336 & 224 & 336 \\
\hline & & & & & & & 2004 & & & & & & & \\
\hline 24. & Mead & Tomek & siCL & soybean & NT & $34,2.2$ & $6.3,0.18$ & $7,2.2$ & $4.9,1.6$ & 322,45 & 168 & 280 & 168 & 280 \\
\hline 25. & Pickrell & Wymore & $s i C L$ & soybean & NT & $28,2.5$ & $6.2,0.19$ & $6,2.8$ & $3.8,1.9$ & 396,59 & 168 & 280 & 168 & 280 \\
\hline 26. & BrunswickT & Thurman & IS & soybean & $\mathrm{CT}$ & $9,2.4$ & $6.3,0.33$ & $21,9.5$ & $11.1,6.2$ & 91,35 & 168 & 280 & 168 & 280 \\
\hline 27. & Concordף & Kennebec & siL & soybean & NT & $28,2.7$ & $6.4,0.16$ & $28,6.5$ & $19.8,4.4$ & 479,70 & 168 & 280 & 168 & 280 \\
\hline 28. & North Bend & Moody & siCL & soybean & $\mathrm{CT}$ & $30,2.3$ & $6.4,0.14$ & $13,8.2$ & $8.6,6.1$ & 458,69 & 168 & 280 & 168 & 280 \\
\hline 29. & Cairo & Hord & siL & corn & RT & $24,2.0$ & $6.7,1.9$ & $22,5.4$ & I2.I, 3.8 & 387,63 & 224 & 336 & 224 & 336 \\
\hline 30. & Funk & Holdrege & siL & corn & RT & $28,2.1$ & $6.8,0.25$ & II, II.4 & $6.5,7.8$ & 529,57 & 224 & 336 & 224 & 336 \\
\hline 31. & SCAL & Butler & siL & soybean & CT & $26,2.1$ & $6.9,0.17$ & $28,9.3$ & $20.3,6.4$ & 492,42 & 168 & 280 & 168 & 280 \\
\hline 32. & Brosius & Hord & $s L$ & corn & CT & $10,2.8$ & $4.8,0.11$ & $88,22.6$ & $45.8,12.1$ & 202,33 & 224 & 336 & 224 & 336 \\
\hline 33. & Spurgin & Vetal & IS & corn & CT & $20,4.3$ & $6.3,0.25$ & $26,6.9$ & $\mid 4.2,4.2$ & 426,86 & 224 & 336 & 224 & 336 \\
\hline 34. & Box Butte & Creighton & $s L$ & drybean & CT & $27,3.5$ & $7.1,0.18$ & $52,8.2$ & $34.5,7.4$ & 706,69 & 224 & 336 & 224 & 336 \\
\hline
\end{tabular}

† Soil series names: Butler, fine, smectitic, mesic Vertic Argiaquolls; Cozad, coarse-silty, mixed, superactive, mesic Typic Haplustolls; Creighton, coarse-loamy, mixed, superactive, mesic Aridic Haplustolls; Crete, fine, smectitic, mesic Pachic Argiustolls; Crofton, fine-silty, mixed, superactive, calcareous, mesic Udic Ustorthents; Hall, fine-silty, mixed, superactive, mesic Pachic Argiustolls; Hastings, fine, smectitic, mesic Udic Argiustolls; Hord, fine-silty, mixed, superactive, mesic Cumulic Haplustolls; Holdrege, fine-silty, mixed, superactive, mesic Typic Argiustolls; Kennebec, fine-silty, mixed, superactive, mesic Cumulic Hapludolls; Mitchell, coarse-silty, mixed, superactive, calcareous, mesic Ustic Torriorthents; Moody, fine-silty, mixed, superactive, mesic Udic Haplustolls; Muir, fine-silty, mixed, superactive, mesic Cumulic Haplustolls; Nora, fine-silty, mixed, superactive, mesic Udic Haplustolls; Thurman, sandy, mixed, mesic Udorthentic Haplustolls; Tomek, fine, smectitic, mesic Pachic Argiudolls; Wymore, fine, smectitic, mesic Aquertic Argiudolls; Vetal, coarse-loamy, mixed, superactive, mesic Pachic Haplustolls.

$\ddagger$ Till = tillage system including conventional tillage consisting of disk or chisel plow tillage (CT), no-till (NT), and ridge till (RT). SOM = soil organic matter. Soil texture classes included silty clay loam (siCL), loamy sand (IS), silt loam (siL), and sandy loam (saL).

$\S$ The $\mathrm{N}$ rates for $\mathrm{P}$ and $\mathrm{K}$ treatments varied by site-year and, in some cases, by rate comparison. $\mathrm{P} 0-20=$ the comparison of the 0 and $20 \mathrm{~kg} P$ ha ${ }^{-1}$ rates; $\mathrm{P} 20-40, \mathrm{~K} 0-40$, and K40-80 have similar meanings. The P0-20 and P20-40 comparisons were with $40 \mathrm{~kg} \mathrm{~K} \mathrm{ha}^{-1}$ applied. The K0-40 and K40-80 comparisons were with $20 \mathrm{~kg}$ P ha ${ }^{-1}$ applied.

II Site-years with treatment for applied sulfur effects. The $\mathrm{N}$ rate was consistent for the 0 and $22 \mathrm{~kg} \mathrm{~S}$ ha ${ }^{-1}$ rate comparisons within each site year but varied across siteyears, $\geq 140 \mathrm{~kg} \mathrm{ha}^{-1}$ for CS and $\geq 252 \mathrm{~kg} \mathrm{ha}^{-1}$ for CC and CDB. The $\mathrm{P}$ and $\mathrm{K}$ rates for $\mathrm{S}$ comparison treatments were 20 and $40 \mathrm{~kg}$ ha ${ }^{-1}$, respectively.

class, SOM, ammonium acetate-exchangeable $\mathrm{K}$, $\mathrm{pH}$, buffer $\mathrm{pH}$, Bray-1 P, Olsen P, and Ca-phosphate-extracted S (Missouri Agricultural Experiment Station, 1998).

A six-plant sample was collected at physiological maturity to determine $\mathrm{P}, \mathrm{K}$, and $\mathrm{S}$ concentrations in grain and stover, and to calculate $\mathrm{P}, \mathrm{K}$, and $\mathrm{S}$ harvest index $(\mathrm{HI})$ and uptake. Grain yield and final plant density were determined from two 6.1-m row segments. Final plot dry matter yield was estimated from the grain yield measured at harvest and the HI value. Grain and aboveground biomass yield, final plant density, and P, K, and $S$ uptake in grain and stover were determined.

\section{Statistical Analysis}

Statistical analyses were conducted using Statistix 9 (Analytical Software, Tallahassee FL). Reported treatment effects and equations were significant when $P<0.05$. Analyses of variance (ANOVA) were conducted for individual site-years using the nine treatments that were consistent across all research sites. The effects of applied $\mathrm{P}$ and $\mathrm{K}$ were determined with linear one-degree-of-freedom contrasts. When it was apparent that the critical soil test $\mathrm{P}$ level for response to applied P differed according to previous crop, combined ANOVA were conducted for the effect of applied P with sets of site-years. These sets were determined in consideration of individual site-year results and 
Table 2. Descriptive statistics for yield, yield components, nutrient uptake, and nutrient use efficiency values for data collected from 34 high yield corn trials conducted in Nebraska $\left(n=1483\right.$ observations). Grain yield is expressed for $155 \mathrm{~g} \mathrm{~kg}^{-1}$ water content whereas other yield and weight variables are on an oven-dry basis.

\begin{tabular}{|c|c|c|c|c|c|c|c|}
\hline \multirow[b]{2}{*}{ Parameter $\dagger$} & \multirow[b]{2}{*}{ Mean } & \multirow[b]{2}{*}{ SD } & \multirow[b]{2}{*}{ Max. } & \multirow[b]{2}{*}{ Min. } & \multicolumn{3}{|c|}{ Lower Upper } \\
\hline & & & & & Median & $25 \%$ & $25 \%$ \\
\hline 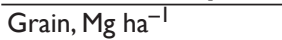 & 13.86 & 2.26 & 19.01 & 3.66 & $|4.2|$ & 12.57 & $|5.5|$ \\
\hline Stover, $\mathrm{Mg} \mathrm{ha}^{-1}$ & 10.14 & 2.81 & 10.14 & 3.56 & 9.78 & 8.07 & 11.79 \\
\hline Cobs, $\mathrm{Mg} \mathrm{ha} \mathrm{h}^{-1}$ & 1.53 & 0.33 & 1.53 & 0.48 & 1.47 & 1.32 & 1.67 \\
\hline Biomass, Mg ha ${ }^{-1}$ & 23.74 & 4.10 & 35.07 & 8.38 & 23.89 & 20.92 & 26.57 \\
\hline 100-grain wt., g & 31.3 & 3.9 & 42.7 & 21.3 & 1.0 & 28.7 & 34.3 \\
\hline Ears $\mathrm{m}^{-2}$ & 7.28 & 0.89 & 12.30 & 3.99 & 7.34 & 6.80 & 7.66 \\
\hline Kernels $\mathrm{m}^{-2}$ & 3867 & 564 & 5939 & 1375 & 3872 & 3556 & 4225 \\
\hline Kernels ear ${ }^{-1}$ & 536 & 87 & 921 & 210 & 528 & 485 & 582 \\
\hline Grain & 69 & 0.80 & 5.15 & 0.77 & .66 & 2.16 & 3.23 \\
\hline Grai & .8 & 12.0 & 70.8 & 6.8 & 1.3 & 23.6 & 41.2 \\
\hline Grai & 63 & 0.64 & 5.63 & 1.60 & 3.65 & 3.21 & 4.09 \\
\hline Grain K, kg & 4.0 & 11.4 & 76.3 & 11.8 & 3.8 & 35.6 & 51.9 \\
\hline $\mathrm{g} \mathrm{kg}^{-1}$ & 1.03 & 0.14 & 1.37 & 0.09 & .03 & 0.93 & 1.13 \\
\hline Grain S, $\mathrm{kg} \mathrm{ha}^{-1}$ & 12.5 & 2.9 & 20.2 & 1.0 & 2.5 & 10.6 & 14.6 \\
\hline Stover $\mathrm{P}, \mathrm{g} \mathrm{kg}{ }^{-1}$ & 0.44 & 0.36 & 2.89 & 0.05 & 0.33 & 0.20 & 0.53 \\
\hline over P, kg & 37.6 & 13.0 & 79.9 & 10.8 & 5.8 & 27.9 & 46.3 \\
\hline-1 & 23.82 & 4.50 & 40.08 & 12.04 & 23.74 & 20.74 & 26.82 \\
\hline Stov & 300.8 & 96.3 & 591.6 & 88.1 & 289.2 & 229.0 & 370.4 \\
\hline Stov & 0.92 & 0.22 & 1.76 & 0.39 & 0.90 & 0.77 & 1.05 \\
\hline Stove & 2.4 & 5.1 & 41.2 & 6.2 & 2.3 & 18.9 & 25.9 \\
\hline $\mathrm{HI}, \mathrm{g}$ & 51 & 0.06 & 0.62 & 0.34 & .52 & 0.47 & 0.56 \\
\hline $\mathrm{PHI}$, & 87 & 0.08 & 0.98 & 0.47 & 0.89 & 0.83 & 0.92 \\
\hline $\mathrm{K} \mathrm{HI}, \mathrm{kg} \mathrm{kg}^{-1}$ & 0.15 & 0.04 & 0.30 & 0.06 & 0.15 & 0.12 & 0.18 \\
\hline $\mathrm{S} \mathrm{HI}, \mathrm{kg} \mathrm{kg}^{-1}$ & 0.56 & 0.07 & 0.79 & 0.08 & 0.56 & 0.51 & 0.61 \\
\hline $\mathrm{PIE}, \mathrm{P}_{0} \ddagger, n=50, \mathrm{~kg} \mathrm{~kg}^{-1}$ & 452 & 102 & 68I & 244 & 438 & 385 & 495 \\
\hline $\mathrm{PIE}, n=1433, \mathrm{k}$ & 405 & 137 & 1105 & 184 & 372 & 303 & 469 \\
\hline $\mathrm{P}$ RIE, $\mathrm{P}_{0}, n=50, \mathrm{~kg} \mathrm{Mg}^{-}$ & 2.32 & 0.53 & 4.09 & 1.47 & 2.28 & 2.02 & 2.59 \\
\hline P RIE, $n=143$ & 2.72 & 0.81 & 5.45 & 0.90 & 2.69 & 2.13 & 3.29 \\
\hline $\mathrm{K} \mathrm{IE}, \mathrm{kg} \mathrm{kg}^{-1}$ & 49.7 & 13.7 & 98.0 & 21.5 & 48.8 & 38.2 & 58.6 \\
\hline $\mathrm{K}$ RIE, $\mathrm{kg} \mathrm{Mg}{ }^{-1}$ & 21.7 & 6.1 & 46.5 & 10.2 & 20.5 & 17.1 & 26.2 \\
\hline S IE, $\mathrm{kg} \mathrm{kg}^{-1}$ & 636 & 115 & 1073 & 314 & 613 & 553 & 697 \\
\hline S RIE, $\mathrm{kg} \mathrm{Mg}^{-1}$ & 1.60 & 0.29 & 3.19 & 0.97 & 1.63 & 1.38 & 1.81 \\
\hline
\end{tabular}

$\dagger \mathrm{HI}$, harvest index; IE, internal efficiency of $\mathrm{P}$ use expressed as grain produced per unit of aboveground plant nutrient uptake at physiological maturity; RIE, reciprocal internal efficiency expressed as amount of plant nutrient uptake per unit of grain produced.

$\ddagger P_{0}=$ determined for the no $P$ applied treatment for corn following corn trials with Bray-I $P<20 \mathrm{mg} \mathrm{kg}^{-1}$ and for corn following soybean trials with Bray-I $P<10 \mathrm{mg} \mathrm{kg}^{-1}$.

included: soybean as the previous crop and Bray- $1 \mathrm{P}<10,>10$, and $>20 \mathrm{mg} \mathrm{kg}^{-1}$; corn as the previous crop with Bray-1 P $<20$ and $>20 \mathrm{mg} \mathrm{kg}^{-1}$; and drybean as the previous crop with Bray-1 $\mathrm{P}>20 \mathrm{mg} \mathrm{kg}^{-1}$. Combined ANOVAs were conducted for applied K effects by previous crop. Combined ANOVAs were conducted by soil texture group for applied $S$ effects using only those treatments necessary for testing the effect of $S$.

Regression analyses were used to relate Bray-1 P to Olsen $\mathrm{P}$ and to determine soil depth effects on Bray-1 P and soil test K. Regression analyses were also used to estimate soil nutrient supply from soil test results and to determine the relationship of nutrient uptake with yield. Internal efficiency of nutrient use, or grain utilization efficiency as grain dry weight per unit of nutrient uptake, was determined for P, K, and S (Witt et al., 1999). Reciprocal IE (RIE), or the amount of nutrient needed to produce $1 \mathrm{Mg}$ of grain, was calculated. Grain yield was related to nutrient uptake using nonlinear regression analysis.

\section{RESULTS AND DISCUSSION}

Bray-1 $\mathrm{P}$ and soil test $\mathrm{K}$ at 0 - to 20 -cm soil depth ranged from 5 to 84 and 93 to $696 \mathrm{mg} \mathrm{kg}^{-1}$, respectively (Table 1 ). The descriptive
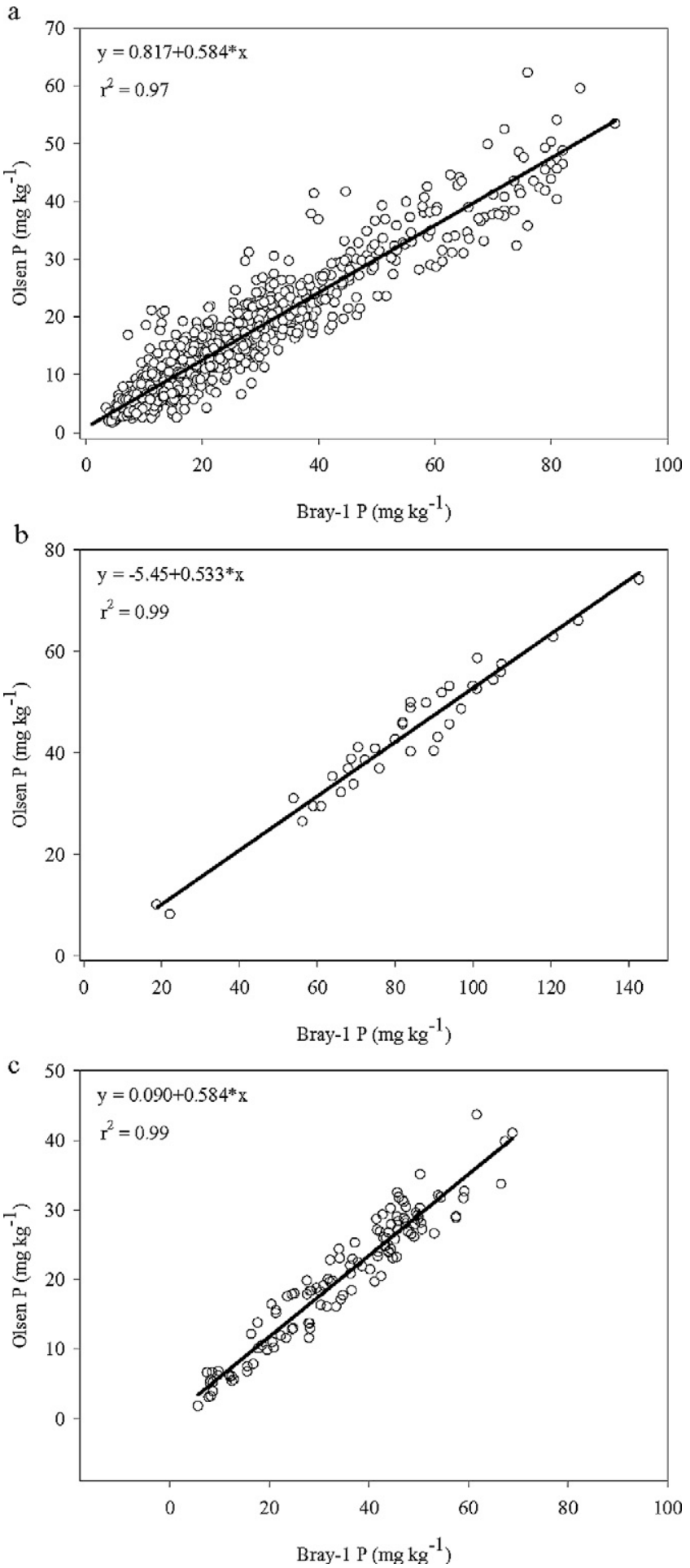

Fig. I. Relationship between Bray-I P and Olsen $\mathbf{P}$ at a sample depth of 0 - to $20-\mathrm{cm}$ for a soil $\mathrm{pH}$ of (a) 5.0 to $7.4(n=1299)$, (b) $<5.0(n=37)$, and (c) $>7.4(n=122)$ for soil samples collected from 34 site-years in Nebraska.

statistics for yield, yield components, nutrient uptake, and nutrient use efficiency for P, K and S were summarized in Table 2.

\section{Soil Test $\mathbf{P}$}

Bray-1 P and Olsen P were highly correlated $\left(r^{2}=0.97\right)$ over the whole range of soil test $\mathrm{P}$ levels, including for the acid and alkaline soil samples (Fig. 1a). However, the $r^{2}$ was only 0.67 when the range of data was limited to Bray- $1 \mathrm{P}<25 \mathrm{mg} \mathrm{kg}^{-1}$, 

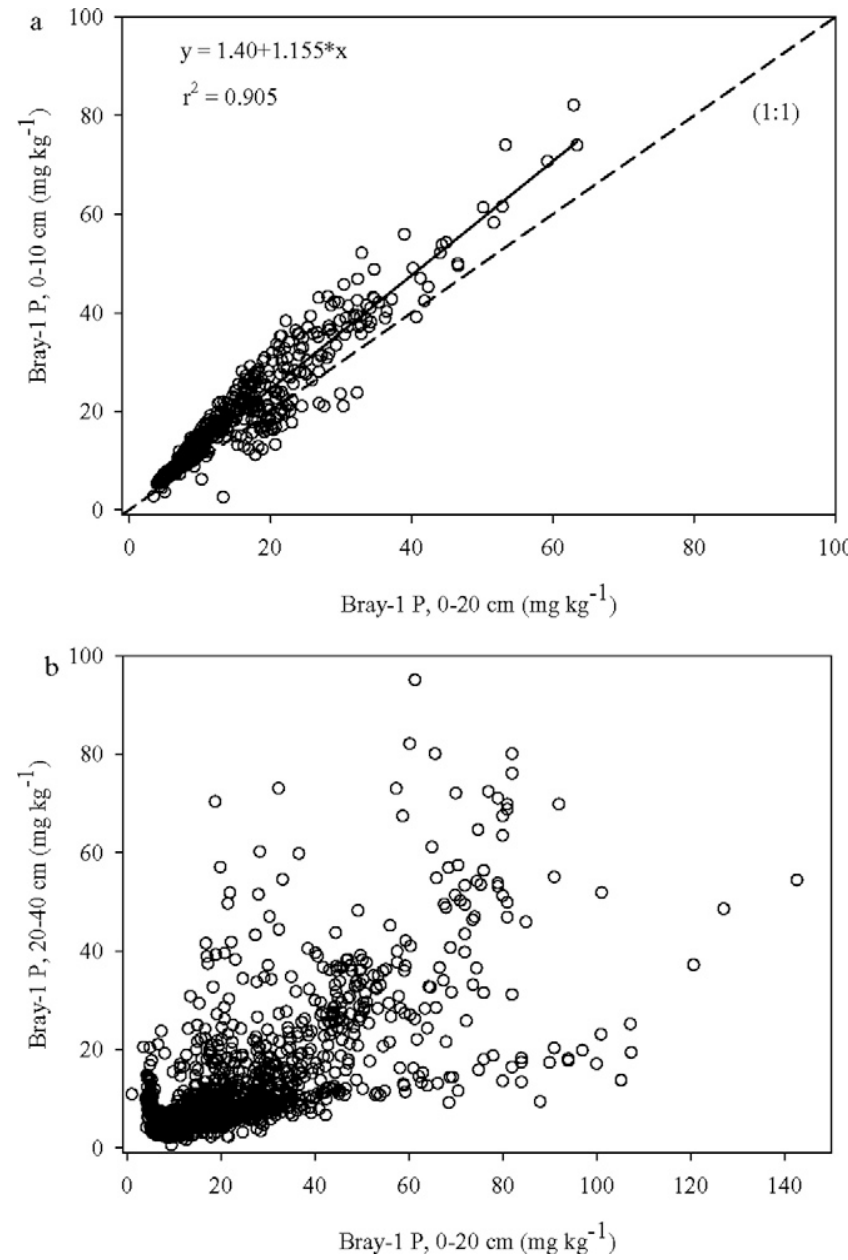

Fig. 2. The relationship of Bray-I P at 0 - to $20-\mathrm{cm}$ with (a) 0 to $10-\mathrm{cm}$ depth for soil samples collected from II no-till siteyears $(n=508)$, and (b) 20 - to $40-\mathrm{cm}$ depths for soil samples collected from 34 site-years $(n=1458)$ in Nebraska.

the important range for agronomic soil $\mathrm{P}$ testing $(\mathrm{Olsen} \mathrm{P}=$ $0.577+0.592$ Bray-1 P). Currently, the UN-L interpretation of soil test $\mathrm{P}$ results uses an Olsen to Bray-1 P ratio of 0.67 (Shapiro et al., 2003). With this data set, the ratio was 0.67 when Bray-1 P was $10 \mathrm{mg} \mathrm{kg}^{-1}$, but the ratio increased and decreased as Bray-1 P decreased or increased from $10 \mathrm{mg} \mathrm{kg}^{-1}$, respectively. When soil $\mathrm{pH}<5$, the ratio increased as soil test $P$ increased as a result of the negative $y$ intercept (Fig. 1b). For alkaline soils, the ratio of Olsen to Bray-1 P is 0.59 over a wide range of soil test $\mathrm{P}$ levels (Fig. 1c). When using the complete data set to relate Olsen to Bray-1 P, the $y$ intercept and the slope were both greater than found by Mallarino and Blackmer (1992).

Bray-1 P values for the 0 - to $10-\mathrm{cm}$ depth were higher but closely related to the values for the 0 - to $20-\mathrm{cm}$ depth at the notill site-years (Fig. 2a). Development of $\mathrm{P}$ stratification under no-till conditions is common (Garcia et al., 2007). Bray-1 P values for the 20 - to $40-\mathrm{cm}$ depth were not related to the values for the 0 - to $20-\mathrm{cm}$ depth (Fig. 2b), differing with the findings of Olson et al. (1958) possibly due to an additional $50 \mathrm{yr}$ of extraction and $\mathrm{P}$ application to surface soil.

Soil test $P$ in the 0 - to $20-\mathrm{cm}$ depth was weakly related to plant P uptake (UP) when no P was applied, but the predictability of UP improved by including SOM and $\mathrm{pH}$ in the model. For corn after corn $(n=47)$, with site-year 32 excluded because of very high soil test $\mathrm{P}$ and low $\mathrm{pH}$, the following was determined:

$$
\begin{aligned}
& \mathrm{UP}=29.04+0.314 \text { Bray- } 1 \mathrm{P}, R^{2}=0.16 \\
& \mathrm{UP}=27.19+0.710 \text { Olsen } \mathrm{P}, R^{2}=0.30 \\
& \mathrm{UP}=18.46+4.17 \mathrm{SOM}+0.0635 \text { Bray- } 1 \mathrm{P} \mathrm{pH}, \\
& R^{2}=0.34
\end{aligned}
$$

For corn following soybean $(n=61)$, soil test $\mathrm{P}$ was related to UP as follows:

$$
\begin{aligned}
& \mathrm{UP}=16.9+1.56 \text { Bray- } 1 \mathrm{P}, R^{2}=0.29 \\
& \mathrm{UP}=19.9+2.01 \text { Olsen } \mathrm{P}, R^{2}=0.27 \\
& \mathrm{UP}=-100.2+1.96 \text { Bray-1 P }-0.020 \text { Bray-1 } \mathrm{P}^{2} \\
& +0.745 \mathrm{SOM}+15.21 \mathrm{pH}, R^{2}=0.61 \\
& \mathrm{UP}=-38.5+1.34 \text { Olsen } \mathrm{P}+10.06 \mathrm{pH}, R^{2}=0.49
\end{aligned}
$$

Soil test $\mathrm{P}$ at 0 - to $10-\mathrm{cm}$ and 20 - to 40 - $\mathrm{cm}$ depths were not significant in these equations. The results generally agree with Janssen et al. (1990), who found that including soil organic $\mathrm{C}$ and $\mathrm{pH}$ with soil test $\mathrm{P}$ improved the estimation of soil $\mathrm{P}$ supply.

There was a trend for soil test $\mathrm{P}$ to be lower and higher where the preceding crop was soybean and dry bean, respectively, compared with corn (Fig. 3). Soil test $\mathrm{P}$ also tended to be less with no-till and more with conventional tillage compared with ridge-till site-years. This was confounded, however, with previous crops as all ridge-till site-years were corn following corn, all corn following dry bean were conventionally tilled, and most of the corn following soybean site-years were no-till fields.

\section{Response to Applied Phosphorus}

The application of $20 \mathrm{~kg} \mathrm{ha}^{-1} \mathrm{P}$ resulted in grain yield increases for four site-years, decreases for two site-years, and no significant effect for other site-years (Table 3). Aboveground biomass yield was affected in five site-years with only two site-years having increased biomass yield with P application. The mean P effect on grain and biomass yield over all site-years was not significant. Grain P was increased in four site-years and plant $P$ uptake was increased in five site-years and the overall means were increased with $\mathrm{P}$ application. Phosphorus $\mathrm{HI}$ was increased and decreased in two and three site-years, respectively, and the overall mean $\mathrm{P}$ HI was reduced with $\mathrm{P}$ application.

The mean response of grain and biomass yield and plant and grain $\mathrm{P}$ uptake to application of $20 \mathrm{~kg} \mathrm{ha}^{-1} \mathrm{P}$ was much greater when the previous crop was corn compared with soybean for Bray-1 P $<20 \mathrm{mg} \mathrm{kg}^{-1}$ and Olsen $\mathrm{P}<12 \mathrm{mg} \mathrm{kg}^{-1}$ (Table 3; Fig. 3). For corn following soybean, response of these traits to applied $\mathrm{P}$ was significant only for Bray-1 $\mathrm{P}<10 \mathrm{mg} \mathrm{kg}^{-1}$ and 
Olsen $\mathrm{P}<7 \mathrm{mg} \mathrm{kg}^{-1}$. Mean $\mathrm{P}$ uptake was greater when the previous crop was soybean compared with corn for Bray-1 $\mathrm{P}<$ 20 but this was because of unusually high $P$ uptake at Brunswick in 2003. When this site-year was excluded, mean plant uptake was 33.0 and 35.1 and grain P uptake was 29.4 and $31.2 \mathrm{~kg} \mathrm{ha}^{-1}$, respectively, for corn following soybean with 0 and $20 \mathrm{~kg} \mathrm{ha}^{-1} \mathrm{P}$ applied. Phosphorus $\mathrm{HI}$ was affected by $\mathrm{P}$ application only with corn following soybean when Bray-1 $\mathrm{P}$ was $>20 \mathrm{mg} \mathrm{kg}^{-1}$. Application of $20 \mathrm{~kg} \mathrm{ha}^{-1} \mathrm{P}$ had no effect on crop performance for Bray-1 P > $20 \mathrm{mg} \mathrm{kg}^{-1}$. Application of an additional $20 \mathrm{~kg} \mathrm{ha}^{-1} \mathrm{P}$ did not result in significant yield increases. Yield response to applied $P$ was associated with increased number of kernels ear ${ }^{-1}$ and $\mathrm{m}^{-2}$ for corn following corn, and with increased ear $\mathrm{m}^{-2}$ and kernel $\mathrm{m}^{-2}$ for corn following soybean (Table 4). Other yield components were not affected by $\mathrm{P}$ application.

Internal P-use efficiency ranged from 1100 to $200 \mathrm{~kg}$ grain $\mathrm{kg}^{-1} \mathrm{UP}$ when plant $\mathrm{P}$ was extremely diluted or concentrated, respectively, with a median of $372 \mathrm{~kg} \mathrm{~kg}^{-1}$ (Table 2). Mean crop $P$ requirement can be estimated for expected grain yield (GY) according to the following quadratic regression equations:

$\mathrm{UP}$ (for all cropping systems) $=35.5-3.28 \mathrm{GY}$

$+0.241 \mathrm{GY}^{2}, R^{2}=0.28, n=1484$

UP (for corn following corn) $=33.8-2.97 \mathrm{GY}$

$+0.220 \mathrm{GY}^{2}, R^{2}=0.50, n=583$

UP (for corn following soybean $)=13.48$

$+0.143 \mathrm{GY}^{2}, R^{2}=0.32, n=700$

The soil test equations for predicting UP did not improve predictiveness of response compared with using soil test $\mathrm{P}$ thresholds. For corn following corn, the mean grain yield response to applied P was $0.70 \mathrm{Mg} \mathrm{ha}^{-1}$ for Bray-1 $\mathrm{P}<20 \mathrm{mg} \mathrm{kg}^{-1}$ compared

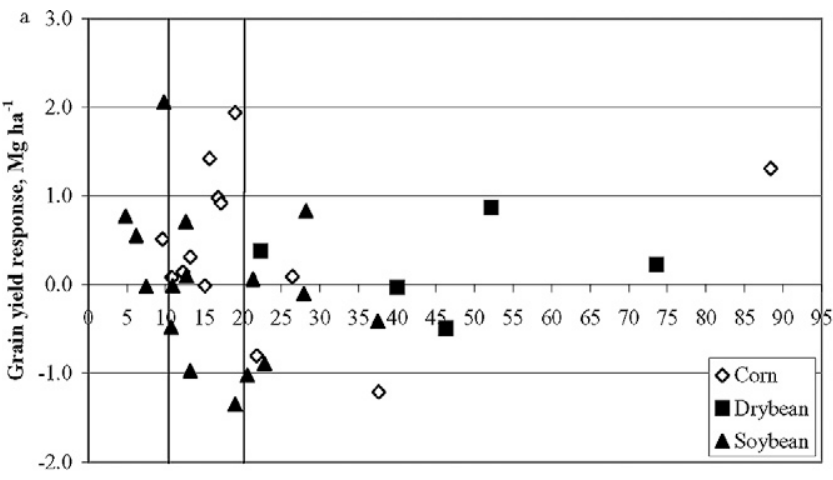

Bray-1 P, 0-20 cm (mg kg $\left.{ }^{-1}\right)$

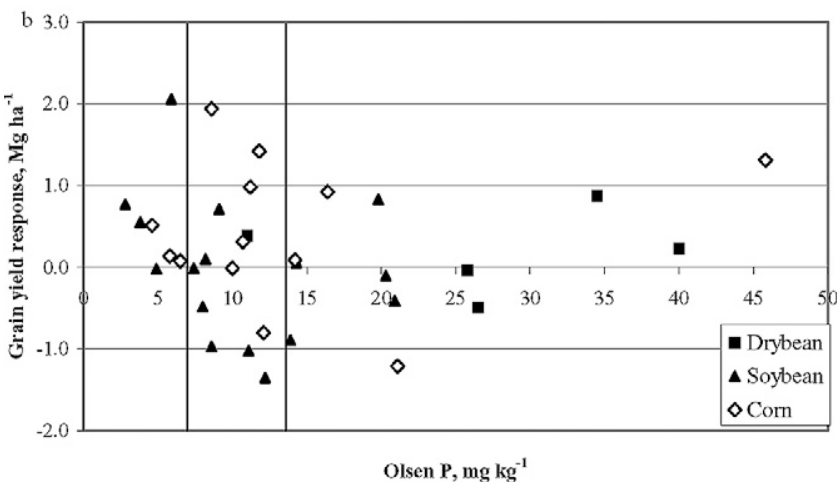

Fig. 3. Corn grain yield response to $20 \mathrm{~kg} \mathrm{ha}^{-1} \mathrm{P}$, relative to (a) Bray-I and (b) Olsen soil test $\mathbf{P}$ with corn, dry bean, or soybean as the preceding crop. Mean response of corn following soybean was significant when Bray-I and Olsen $P$ were less than 10 and $7 \mathrm{mg} \mathrm{kg}^{-1}$, respectively. Mean response of corn following corn was significant when Bray-I and Olsen P were less than 20 and $13.5 \mathrm{mg} \mathrm{kg}^{-1}$, respectively.

with $0.67 \mathrm{Mg} \mathrm{ha}^{-1}$ for the best selection of sites with the complex soil test equation. The threshold for response was $37 \mathrm{~kg} \mathrm{ha}^{-1}$ of UP. For corn following soybean, the mean grain yield response to applied $\mathrm{P}$ was $0.84 \mathrm{Mg} \mathrm{ha}^{-1}$ for Bray-1 $\mathrm{P}<$ $10 \mathrm{mg} \mathrm{kg}^{-1}$ compared with $0.49 \mathrm{Mg} \mathrm{ha}^{-1}$ for the best selection

Table 3. The effect of 20 compared with $0 \mathrm{~kg} \mathrm{ha}^{-1} \mathrm{P}$ applied to corn in 34 trials conducted in Nebraska on yield, $\mathrm{P}$ uptake, and $\mathrm{P}$ HI. Grain yield is expressed for $155 \mathrm{~g} \mathrm{~kg}^{-1}$ water content while biomass yield, $\mathrm{HI}$ and $\mathrm{P}$ uptake are on an oven-dry basis.

\begin{tabular}{|c|c|c|c|c|c|c|c|c|c|c|}
\hline \multirow[b]{3}{*}{ Bray-I P } & \multicolumn{10}{|c|}{$P$ rate, $\mathrm{kg} \mathrm{ha}^{-\mathrm{I}}$} \\
\hline & 0 & 20 & 0 & 20 & 0 & 20 & $\mathbf{0}$ & 20 & $\mathbf{0}$ & 20 \\
\hline & \multicolumn{2}{|c|}{ Grain yield } & \multicolumn{2}{|c|}{ Biomass yield } & \multicolumn{2}{|c|}{ Grain $P$ uptake } & \multicolumn{2}{|c|}{ Total P uptake } & \multicolumn{2}{|c|}{ P HI } \\
\hline $\mathrm{mg} \mathrm{kg}^{-1}$ & \multicolumn{4}{|c|}{$\mathrm{Mg} \mathrm{ha}^{-1}$} & \multicolumn{4}{|c|}{$\mathrm{kg} \mathrm{ha}^{-1}$} & \multicolumn{2}{|c|}{$\mathrm{kg} \mathrm{kg}^{-1}$} \\
\hline \multicolumn{11}{|c|}{ Previous crop $=$ soybean } \\
\hline$<10, n=4 \dagger$ & $12.80 \ddagger$ & $13.73 *$ & $20.12 \S$ & $21.82 *$ & 26.96 & $31.91 * *$ & 30.04 & $34.70^{*}$ & 0.90 & 0.92 \\
\hline$>10, n=11$ & 14.34 & $14.08 \ddagger$ & 24.59 & 24.12 & 37.62 & 37.54 & 42.66 & 43.21 & 0.88 & 0.87 \\
\hline$>20, n=5$ & 14.35 & 14.12 & 24.87 & 24.89 & 42.57 & 42.49 & 47.66 & 48.92 & 0.89 & $0.86^{*}$ \\
\hline \multicolumn{11}{|c|}{ Previous crop $=$ corn } \\
\hline$\leq 20, n=9$ & 13.99 & $14.69 * *$ & 24.31 & $25.60 * * *$ & 30.86 & $35.60 * * *$ & 33.56 & $39.04 * * *$ & 0.92 & 0.91 \\
\hline$>20, n=5$ & 14.46 & 14.32 & 26.72 & 26.25 & 30.34 & 31.58 & 32.52 & 34.98 & 0.93 & 0.90 \\
\hline \multicolumn{11}{|c|}{ Previous crop $=$ drybean } \\
\hline$P>20, n=5$ & 13.90 & 14.18 & 22.11 & 22.42 & 21.98 & 22.66 & 26.21 & 27.60 & 0.84 & 0.82 \\
\hline \multicolumn{11}{|c|}{ Overall } \\
\hline & 14.04 & 14.23 & 23.90 & 24.24 & 31.41 & $33.47 * * *$ & 35.14 & $37.87 * * *$ & 0.89 & $0.88^{*}$ \\
\hline
\end{tabular}

* P interaction was significant at $P=0.05$.

** $\mathrm{P}$ interaction was significant at $P=0.01$.

** $P$ interaction was significant at $P=0.001$.

$\dagger n=$ number of site-years.

$\ddagger P$ interaction was significant at $P=0.1$.

$\S$ Treatment effects were not significant at $P<0.1$ if significance is not indicated. Application of an additional $20 \mathrm{~kg} \mathrm{ha}^{-1} \mathrm{P}$ did not affect the overall means. 
Table 4. The effect of 20 compared with $0 \mathrm{~kg} \mathrm{P} \mathrm{ha}^{-1}$ applied to corn in 34 trials conducted in Nebraska on yield components and $\mathrm{P}$ use efficiency.

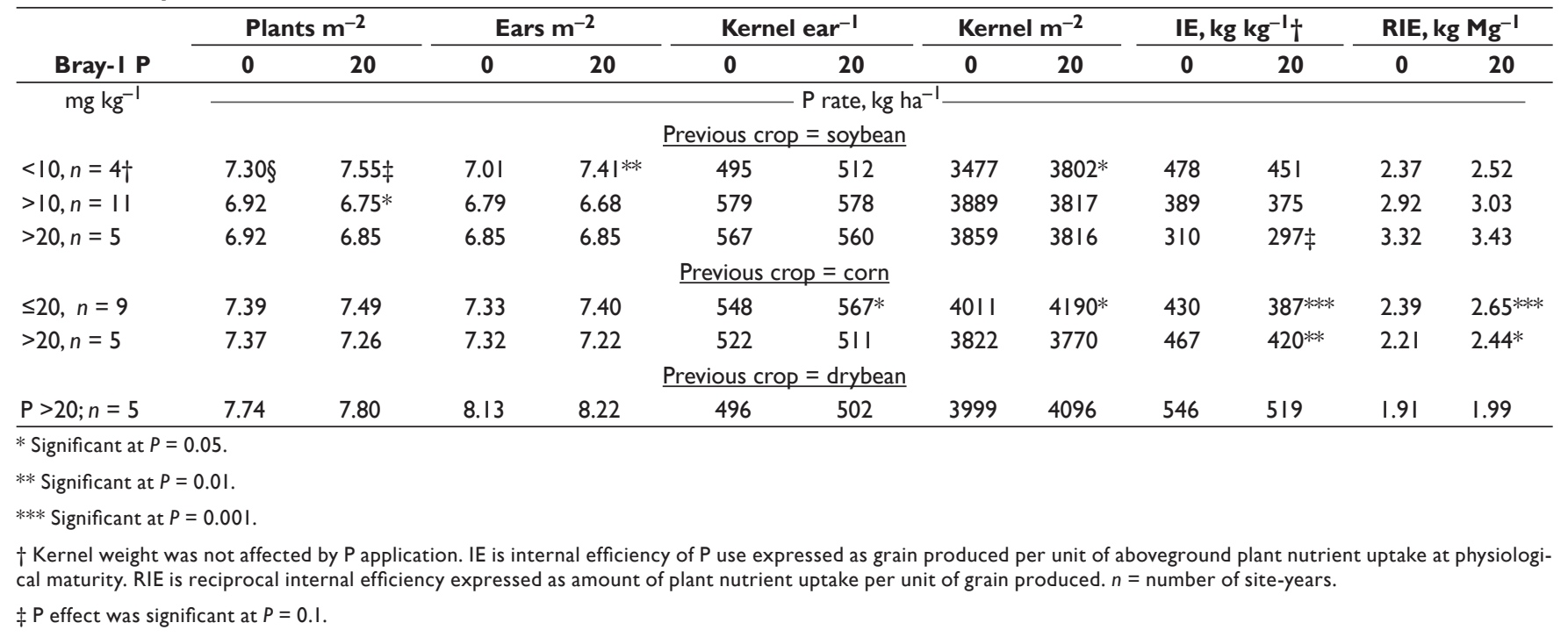

$\S$ Treatment effects were not significant at $P<0.1$ if significance is not indicated. Application of an additional $20 \mathrm{~kg} \mathrm{ha}^{-1} \mathrm{P}$ did not affect the overall means.

of sites with the complex soil test equation. The threshold for response was $39 \mathrm{~kg} \mathrm{ha}^{-1}$ of UP.

The P IE levels are generally high compared with those reported for corn by Janssen and de Willigen (2006) with their median value of 350 compared to $372 \mathrm{~kg} \mathrm{~kg}^{-1}$ (Table 2). The IE level for extremely concentrated $\mathrm{P}$ is comparable to that found for rice (Oryza sativa L.) (Witt et al., 1999) while the level at extreme dilution is $33 \%$ higher than for rice. There were trends of increased IE $(r=0.62)$ and decreased RIE $(r=-0.52)$ of $\mathrm{P}$ use with increase in Bray-1 $\mathrm{P}$ when the previous crop was soybean. These trends were weaker when the previous crop was corn with $r=0.41$ and -0.33 for IE and RIE, respectively. Application of $\mathrm{P}$, compared with no $\mathrm{P}$ applied, resulted in decreased IE and increased RIE when the previous crop was corn (Table 4). The agronomic efficiency of use values for 20 $\mathrm{kg} \mathrm{ha}^{-1}$ applied $\mathrm{P}$ were $0.23,0.25$, and $46.5 \mathrm{~kg} \mathrm{~kg}^{-1}$ of applied $\mathrm{P}$ for plant $\mathrm{P}$, grain $\mathrm{P}$, and grain yield, respectively, when the previous crop was soybean and Bray- $1 \mathrm{P}<10$. Corresponding values when the previous crop was corn and Bray- $1 \mathrm{P}$ was $<20$ were $0.27,0.24$, and $35.0 \mathrm{~kg} \mathrm{~kg}^{-1}$ of applied $P$ for plant $P$, grain $\mathrm{P}$, and grain yield, respectively.

The results suggest lower soil test $\mathrm{P}$ critical levels for corn following soybean compared with continuous corn. Bordoli and Mallarino (1998) reported yield increase with applied $P$ only when Bray-1 P was less than $12 \mathrm{mg} \mathrm{kg}^{-1}$ for corn following soybean. Mallarino and Blackmer (1992) reported results for 24 trials including 9 and 16 with corn and soybean as the previous crop. For corn following soybean, their mean grain yield responses to $25 \mathrm{~kg} \mathrm{ha}^{-1} \mathrm{P}$ were $1.15,0.50$, and $0.01 \mathrm{Mg} \mathrm{ha}^{-1}$ when Bray- $1 \mathrm{P}$ was $<10,10$ to 20 , and $>20 \mathrm{mg} \mathrm{kg}^{-1}$, respectively. For corn following corn, their mean responses were 1.03 and $0.38 \mathrm{Mg} \mathrm{ha}^{-1}$ when Bray- $1 \mathrm{P}$ was $<15$ and $\geq 20 \mathrm{mg} \mathrm{kg}^{-1}$, respectively. Dodd and Mallarino (2005), however, found the critical level for Bray-1 P for corn following soybean to be between 15 and $21 \mathrm{mg} \mathrm{kg}^{-1}$.

Grain yield response of corn to applied P, relative to soil test $\mathrm{P}$, was greater when the previous crop was corn compared with soybean. This may have been because of greater net release of $\mathrm{P}$ from SOM and crop residues when the previous crop was soybean. Crop residue was more when the previous crop was corn compared with soybean, but most corn after corn site-years had ridge or other tillage before planting. Therefore, lower soil temperature and slower root growth were not likely causes for the greater response to $P$ when the previous crop was corn rather than soybean. Verma et al. (2005) found the net gain in ecosystem $\mathrm{C}$ under irrigation was near neutral with continuous corn but negative with the soybean-corn rotation. More P may be released and available to early crop growth with soybean residues compared with corn because of more decomposition, especially of leaves and nodules, during the late summer, fall, and early spring before planting corn. More organic $\mathrm{P}$ is likely mineralized during the growing season for corn following corn compared with corn following soybean, as indicated by soil surface $\mathrm{CO}_{2}$ flux (Amos et al., 2007). This would supply more $\mathrm{P}$ during as compared with before the growing season. At Bray-1 $\mathrm{P}<20 \mathrm{mg} \mathrm{kg}^{-1}$, there is no evidence that the corn-arbuscular mycorrhizal association was more effective in plant $\mathrm{P}$ uptake with corn following soybean compared with continuous corn. Phosphorus uptake was less with corn following soybean, if the Brunswick 2003 site-year is excluded, even though mean grain yield was similar with no $P$ applied for the two cropping systems.

Fertilizer $\mathrm{P}$ was surface-applied without incorporation for all site-years. While response to $\mathrm{P}$ might have been greater with incorporated or injected $\mathrm{P}$, this is not likely as Wortmann et al. (2006a, 2006b) and Bordoli and Mallarino (1998) found similar responses with surface application compared with injected or incorporated.

An economic analysis illustrates the practical significance of the effect of the previous crop on response to $\mathrm{P}$ (Table 3 ). When Bray-1 $\mathrm{P}<20 \mathrm{mg} \mathrm{kg}^{-1}$ and the preceding crop was corn, the fertilizer $\mathrm{P} /$ corn price $\left(\$ \mathrm{~kg}^{-1}\right)$ ratio needs to be less than 35 to pay for the purchase of broadcast-applied fertilizer P; a lower ratio will be needed to cover accompanying interest, procurement, application, and other costs. When the preceding 
crop was soybean and Bray-1 P $<10 \mathrm{mg} \mathrm{kg}^{-1}$, the fertilizer P/ corn price $\left(\$ \mathrm{~kg}^{-1}\right)$ ratio needs to be less than 45 to pay for the purchase of broadcast-applied fertilizer $P$. The results show that when Bray-1 P is above these levels, probability of economical yield gain during the year of application is very low, although there may be longer-term value in the maintenance of soil test $\mathrm{P}$ levels. When fertilizer P cost is high relative to other operational costs, band application at a half-rate may be preferred to broadcast application (Shapiro et al., 2003) or deferring broadcast $\mathrm{P}$ application to a future year with more favorable $\mathrm{P}$ prices might be considered.

\section{Potassium}

Three sites with loamy sand soil had soil test K levels below $125 \mathrm{mg} \mathrm{kg}^{-1}$, the UN-L critical level for $\mathrm{K}$ application (Shapiro et al., 2003). Soil test $\mathrm{K}$ at 0 - to 20-cm and 20- to 40- cm depths was highly correlated (Fig. 4b), agreeing with the findings of Olson et al. (1958). Soil test K accounted for only $11 \%$ of the variation in UK over all cropping systems when no $\mathrm{K}$ was applied. Prediction of soil K supply with no K applied was improved by including $\mathrm{pH}$ and SOM in the equation.

$$
\begin{aligned}
& \text { UK (all cropping systems) }=137.4+0.81 \mathrm{~K} \\
& -0.000531 \mathrm{~K}^{2}+68.2 \mathrm{pH}-8.70 \mathrm{pH}^{2} \\
& -57.9 \mathrm{SOM}, R^{2}=0.28, n=135 \\
& \mathrm{UK} \text { (corn following corn) }=-1300-2.06 \mathrm{~K} \\
& -0.00158 \mathrm{~K}^{2}+713.1 \mathrm{pH}-78.3 \mathrm{pH}^{2}-2.16 \mathrm{SOM} \\
& -0.888 \mathrm{SOM}^{2}+0.578 \mathrm{pH} \mathrm{K}, R^{2}=0.41, n=52 \\
& \mathrm{UK}(\text { corn following soybean })=212.6+0.304 \mathrm{~K} \\
& -0.547 \mathrm{SOM}{ }^{2}, R^{2}=0.21 ; \text { or } \\
& =201.1+0.226 \mathrm{~K} ; R^{2}=0.17, n=63
\end{aligned}
$$

Soil test $\mathrm{K}$ for the 0 - to $10-\mathrm{cm}$ and 20 - to $40-\mathrm{cm}$ depths was not significant in these models. As with soil test $\mathrm{P}$, the $R^{2}$ values were often small but predictability of UK was greatly improved by considering soil organic matter and soil $\mathrm{pH}$, as compared with soil test $\mathrm{K}$ alone. Application of $\mathrm{K}$ through irrigation at some sites may have reduced the predictability of $U K$.

There was no yield increase with $\mathrm{K}$ application and a small but significant mean yield decrease over all site-years (Table 5). The site-years with the greatest negative, although not always
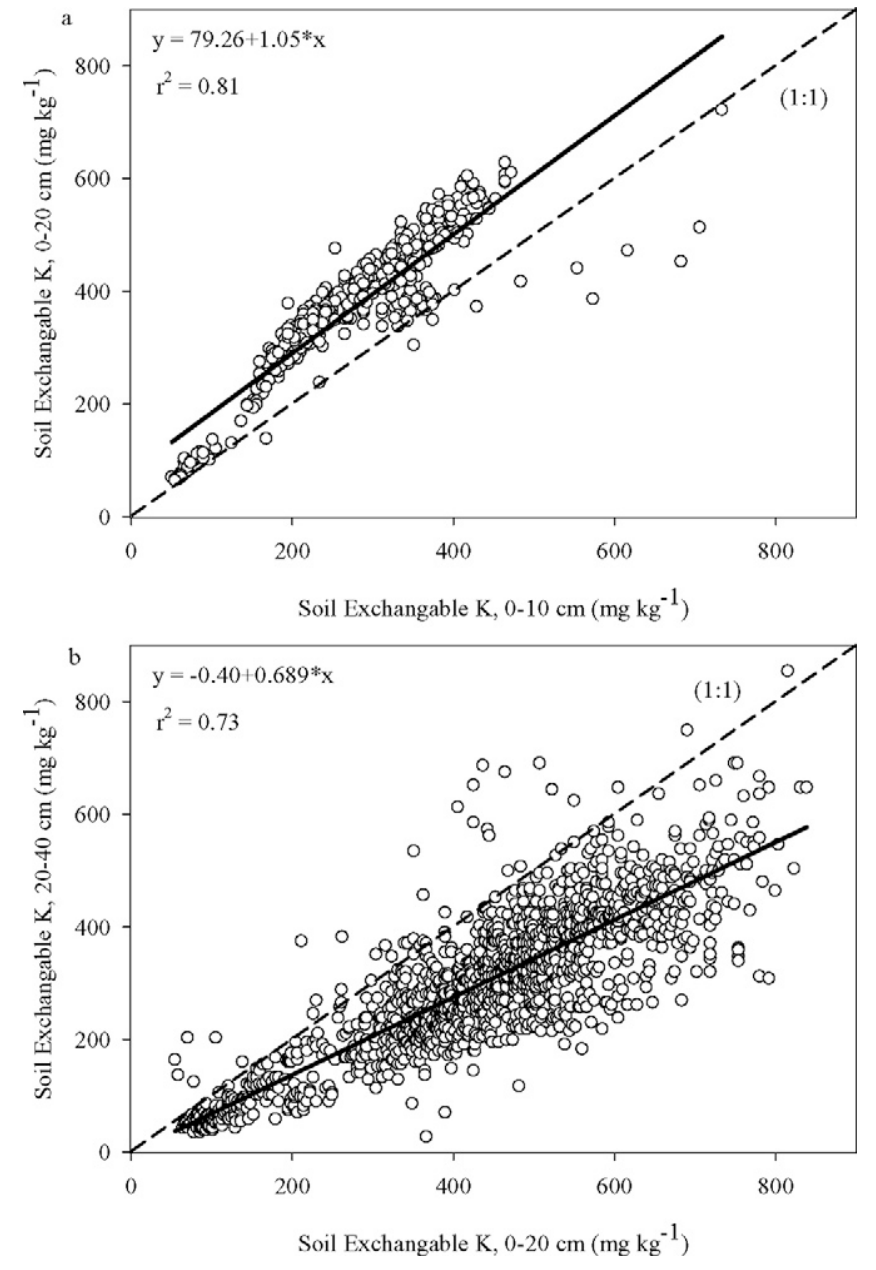

Fig. 4. The relationship of soil exchangeable $K$ at $0-$ to $20-\mathrm{cm}$ with (a) 0 - to $10-\mathrm{cm}$ depth $(n=468)$ and (b) 20 - to $40-\mathrm{cm}$ depth $(n=1458)$ for soil samples collected from 34 site-years in Nebraska.

significant, effect of $\mathrm{K}$ application were Concord and Cairo in 2002, Mead in 2003, and Brunswick in 2004. Overall, grain and biomass yield and total $\mathrm{K}$ uptake were reduced by applica-

\begin{tabular}{|c|c|c|c|c|c|c|c|c|c|c|c|c|}
\hline \multirow{2}{*}{$\begin{array}{l}\text { Previous } \\
\text { crop }\end{array}$} & \multicolumn{2}{|c|}{$\begin{array}{c}\text { Grain yield, Mg } \\
h^{h^{-1}}\end{array}$} & \multicolumn{2}{|c|}{$\begin{array}{c}\text { Biomass yield, kg } \\
\text { ha }^{-1}\end{array}$} & \multicolumn{2}{|c|}{ Plant K, kg ha ${ }^{-1}$} & \multicolumn{2}{|c|}{$\begin{array}{l}100 \text { kernel } \\
\text { wt., } g\end{array}$} & \multicolumn{2}{|c|}{ IE, $\mathbf{~ k g ~ k g}^{-1} \dagger$} & \multicolumn{2}{|c|}{ RIE, $\mathbf{k g ~ M g}^{-1}$} \\
\hline & 0 & 40 & 0 & 40 & 0 & 40 & 0 & 40 & 0 & 40 & 0 & 40 \\
\hline Soybean & $14.38 \ddagger$ & $13.99 *$ & 23.97 & 23.54 & 287.1 & 283.7 & 32.71 & $32.10 *$ & 53.8 & 53.2 & 19.8 & 20.1 \\
\hline Corn & 14.75 & 14.57 & 26.12 & 25.80 & 345.5 & 341.1 & 31.71 & 32.69 & 46.7 & 46.5 & 23.6 & 23.5 \\
\hline Dry bean & 14.16 & 14.18 & 23.36 & 22.41 & 285.9 & $261.9+$ & 30.87 & 30.29 & 51.7 & 56.0 & 20.3 & 18.5 \\
\hline$\dagger$ Indicate that & effect of & applicatio & ignificant & $=0.10$. & & & & & & & & \\
\hline $\begin{array}{l}\ddagger \text { Trea } \\
\text { bean, } \\
\text { cantly }\end{array}$ & & & & & & & 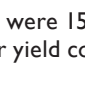 & mo & fo & 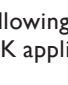 & $\therefore$ & $\begin{array}{l}d \text { dry } \\
\text { ignifi- }\end{array}$ \\
\hline
\end{tabular}
tion of $40 \mathrm{~kg} \mathrm{ha}^{-1} \mathrm{~K}$. Internal K-use efficiency ranged from 83 to $28 \mathrm{~kg}_{\text {grain }} \mathrm{kg}^{-1} \mathrm{UK}$ when plant $\mathrm{K}$ was extremely diluted or concentrated, respectively (Table 2). The K IE levels are generally low compared with those reported for corn by Janssen and de Willigen (2006), with a median value of 65 compared with $49 \mathrm{~kg} \mathrm{~kg}^{-1}$ in this study.

Table 5. The mean effect of $40 \mathrm{~kg} \mathrm{ha}^{-1} \mathrm{~K}$ applied to corn in 34 trials conducted in Nebraska. Grain yield is expressed for $155 \mathrm{~g} \mathrm{~kg}^{-1}$ water content whereas other variables were determined on an oven-dry basis. 
Mean crop K requirement can be estimated for the expected yield.

$$
\begin{aligned}
& \text { UK (all cropping systems) }=130.5 \\
& +0.8635 \mathrm{GY}^{2}, R^{2}=0.28, n=1484 \\
& \mathrm{UK} \text { (corn following corn) }=92.8 \\
& +16.84 \mathrm{GY}, R^{2}=0.16, n=583 \\
& \mathrm{UK} \text { (corn following soybean) }=-75.9 \\
& +26.55 \mathrm{GY}, R^{2}=0.41, n=700
\end{aligned}
$$

Lack of responsive site-years in this study prevented verification of the value of the soil test equations as well as UK estimation based on yield for prediction of $\mathrm{K}$ responsive sites.

Internal efficiency of $\mathrm{K}$ use was not affected by $\mathrm{K}$ application but was relatively low when the previous crop was corn rather than soybean or dry bean. Internal efficiency decreased $(r=$ $-0.30)$ and RIE increased $(r=0.25)$ with increasing soil test $\mathrm{K}$. The K IE levels for extremely diluted and concentrated K are low compared to those found for rice (Witt et al., 1999). The results confirm that the UN-L recommendation does not under-recommend $\mathrm{K}$ application.

Fertilizer K was broadcast-applied without incorporation, which has been shown to be as effective as deep or shallow banded K (Vyn et al., 2002) unless early season drought conditions occur (Bordoli and Mallarino, 1998). Such drought conditions did not occur in these irrigated trials. Yield depression with $\mathrm{K}$ application has been observed in other studies in Nebraska. Miany (1980) reported the yield depression with K application in eastern Nebraska but uptake of other nutrients was not affected. McCallister et al. (1987) suggested that the yield depression may be due to induced P deficiency. This may result from $P$ reaction with cations released from the exchange complex following $\mathrm{K}$ application to form low solubility $\mathrm{P}$ compounds.

\section{Sulfur}

There was not a significant effect on yield with applied $S$ at any of the 11 site-years where $S$ rate treatments were included. Sulfur IE increased $(r=0.56)$ and RIE decreased $(r=-0.51)$ with increasing soil test $S$ across all site-years. Internal $S$-use

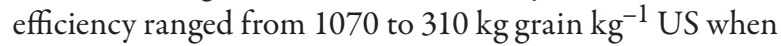
plant $S$ was extremely diluted or concentrated, respectively, with a median of $610 \mathrm{~kg} \mathrm{~kg}^{-1}$ (Table 2). Typical crop $S$ requirement can be estimated for an expected yield.

$$
\begin{aligned}
& \text { US (all cropping systems) }=1.841 \\
& +1.483 \times \mathrm{GY}, R^{2}=0.44, n=1484 \\
& \text { US (corn following corn) }=11.18 \\
& +0.0603 \mathrm{GY}^{2}, R^{2}=0.62, n=583 \\
& \text { US (corn following soybean) }=2.998 \\
& +1.442 \mathrm{GY}, R^{2}=0.41, n=700
\end{aligned}
$$

For a grain yield of $15 \mathrm{Mg} \mathrm{ha}^{-1}$, mean US is estimated to be $24 \mathrm{~kg} \mathrm{Sha}^{-1}$.
The results are consistent with the UN-L recommendation for medium and fine texture soil (Shapiro et al., 2003) and the findings of Wortmann et al. (2006a, 2006b), who did not observe a corn or grain sorghum response to applied $S$ on medium and fine-texture no-till soils in eastern Nebraska. Soil organic matter was above $10 \mathrm{mg} \mathrm{kg}^{-1}$ for three of the five site-years with sandy soil and response to $S$ was not expected. Site-year 3, Brunswick in 2002, was a likely place for yield response to $S$ because of sandy soil, low soil organic matter, and low Ca-phosphate-extracted $S$, but the yield increase of 0.34 $\mathrm{Mg} \mathrm{ha}^{-1}$ with $\mathrm{S}$ application was not significant.

Soil test information did not account for variation in US for the loamy sand soil when no $S$ was applied. The interactions of soil $\mathrm{S}$ with SOM and $\mathrm{pH}$ were important in accounting for US on medium and fine-texture soils with no $S$ applied:

$$
\begin{aligned}
& \text { US }=22.07-0.175 \mathrm{pH} \mathrm{S}+0.0478 \\
& \text { SOM S; } R^{2}=0.28, n=229
\end{aligned}
$$

Lack of responsive site-years in this study prevented verification of the value of the soil test equations as well as US estimation based on yield for prediction of $S$ responsive sites.

\section{CONCLUSION}

This research was conducted across a wide range of temperate high yield corn production conditions and the results should be widely applicable to high yield corn production of similar day lengths. The results indicate a need to revise the critical level for Bray-1 P from 15 to $20 \mathrm{mg} \mathrm{kg}^{-1}$ for high-yield corn following corn but not for corn following soybean. Further research is needed to better understand the effect of previous crop on corn response to applied P. The Olsen soil P test is often used for alkaline soils in place of Bray-1, but Bray-1 and Olsen were closely related when soil $\mathrm{pH}$ was above 7.4 with an Olsen/Bray-1 P ratio of 0.59. Equations that consider soil organic matter and $\mathrm{pH}$ as well as soil test $\mathrm{P}, \mathrm{K}$, or $S$ generally accounted for more variation in nutrient uptake than the nutrient tests alone. However, the more complex soil test equations were not better than soil test $\mathrm{P}$ thresholds for identifying $\mathrm{P}$ responsive site-years. The results confirm the UN-L recommendations for $\mathrm{K}$ and $\mathrm{S}$ that yield response to applied $\mathrm{K}$ is unlikely if soil test $\mathrm{K}$ is above $125 \mathrm{mg} \mathrm{kg}^{-1}$ and response to applied $\mathrm{S}$ is not likely on medium and fine-texture soils or on sandy soils with more than $10 \mathrm{mg} \mathrm{kg}^{-1} \mathrm{SOM}$. Use of soil analysis results to estimate the capacity of soil to supply $\mathrm{K}$, and $\mathrm{S}$ for medium and fine-texture soil, may be improved by considering SOM and/or soil $\mathrm{pH}$ in the interpretation. Grain produced per unit of $\mathrm{P}$ and $\mathrm{S}$ uptake increased as soil test $\mathrm{P}$ and $\mathrm{S}$ increased, respectively, but K IE decreased as soil test $\mathrm{K}$ increased. Sulfur uptake can be better estimated from grain yield than can $\mathrm{P}$ and $\mathrm{K}$ uptake.

\section{REFERENCES}

Amos, B., H. Shen, T.J. Arkebauer, and D.T. Walters. 2007. Effect of previous crop residue on soil surface carbon dioxide flux in maize. Soil Sci. 172:589-597.

Bordoli, J.M., and A.P. Mallarino. 1998. Deep and shallow banding of phosphorus and potassium as alternatives to broadcast fertilization of no-till corn. Agron. J. 90:27-33.

Dodd, J.R., and A.P. Mallarino. 2005. Soil-test phosphorus and crop grain yield response to long-term phosphorus fertilization of corn-soybean rotations. Soil Sci. Soc. Am. J. 69:1118-1128. 
Eghball, B., and D.H. Sander. 1989a. Band spacing effects of dual-placed nitrogen and phosphorus fertilizers on corn. Agron. J. 81:178-184.

Eghball, B., and D.H. Sander. 1989b. Distance and distribution effects of phosphorus fertilizer on corn. Soil Sci. Soc. Am. J. 53:282-287.

Eghball, B., D.H. Sander, and J. Skopp. 1990. Diffusion, adsorption and predicted longevity of banded phosphorus fertilizer in three soils. Soil Sci. Soc. Am. J. 54:1161-1165.

Fawzi, M.A.H.A., and J.V. Drew. 1966. The importance of illite as a source of potassium in Nebraska soils. Soil Sci. Soc. Am. Proc. 30:242-245.

Fox, R.L., R.A. Olson, and H.F. Rhoades. 1964. Evaluating the sulfur status of soils by plant and soil tests. Soil Sci. Soc. Am. Proc. 28:243-246.

Garcia, J.P., C.S. Wortmann, M. Mamo, R.A. Drijber, J.A. Quincke, and D. Tarkalson. 2007. One-time tillage of no-till: Effects on nutrients, mycorrhizae, and phosphorus uptake. Agron. J. 99:1093-1103.

Janssen, B.H., F.C.T. Guiking, D. van der Eijk, E.M.A. Smaling, J. Wolf, and H. van Reuler. 1990. A system for quantitative evaluation of the fertility of tropical soils (QUEFTS). Geoderma 46:299-318.

Janssen, B.H., and P. de Willigen. 2006. Ideal and saturated soil fertility as bench marks in nutrient management: I. Outline of the framework. Agric. Ecosyst. Environ. 116:132-146.

Mallarino, A.P., and A.M. Blackmer. 1992. Comparison of methods for determining critical concentrations of soil test phosphorus for corn. Agron. J. 84:850-856.

Mallarino, A.P., and A.M. Blackmer. 1994. Profit-maximizing critical values of soil-test potassium for corn. J. Prod. Agric. 7:261-268.

Mallarino, A.P., and R. Borges. 2006. Phosphorous and potassium distribution in soil following long-term deep-band fertilization in different tillage systems. Soil Sci. Soc. Am. J. 70:702-707.

McCallister, D.L., C.A. Shapiro, W.R. Raun, F.N. Anderson, G.W. Rehm, O.P. Engelstad, M.P. Russelle, and R.A. Olson. 1987. Rate of phosphorus and potassium buildup/decline with fertilization for corn and wheat on Nebraska Mollisols. Soil Sci. Soc. Am. J. 51:1646-1652.

Miany, F. 1980. Crop and soil response to applied P and K in a long term buildup/depletion study. M.S. thesis. Univ. of Nebraska, Lincoln.

Missouri Agricultural Experiment Station. 1998. Recommended chemical soil test procedures for the North Central Region. North Central Regional Publ. 221. Missouri Agric. Exp. Stn., Columbia MO.

Olson, R.A., F.N. Anderson, K.D. Frank, P.H. Grabouski, G.W. Rehm, and C.A. Shapiro. 1987. Soil testing interpretations: Sufficiency vs. build-up and maintenance. SSSA Special Publ. 21. p. 41-52. In J.R. Brown (ed.) Soil testing: Sampling, correlation, calibration, and intepretation. SSSA, Madison,WI.

Olson, R.A., A.F. Dreier, and R.C. Sorensen. 1958. The significance of subsoil and soil series in Nebraska soil testing. Agron. J. 50:185-188.

Olson, R.A., K.D. Frank, P.H. Grabouski, and G.W. Rehm. 1982. Economic and agronomic impacts of varied philosophies of soil testing. Agron. J. 74:492-499.

Olson, R.A., M.B. Rhodes, and A.F. Dreier. 1954. Available phosphorus status of Nebraska soils in relation to series classification, time of sampling and method of measurement. Agron. J. 46:175-180.

Raun, W.R., D.H. Sander, and R.A. Olson. 1987. Phosphorus fertilizer carriers and their placement for minimum till corn under sprinkler irrigation. Soil Sci. Soc. Am. J. 51:1055-1062.
Rehm, G.W. 1978. Sulfur fertilization of alfalfa and corn on sandy soils of Nebraska. Res. Bull. 284. Univ. of Nebraska, Lincoln.

Rehm, G.W. 1984. Source and rate of sulfur for corn production. J. Fert. Issues 3:99-103.

Rehm, G.W. 1993. Timing sulfur applications for corn (Zea mays L.). Commun. Soil Sci. Plant Anal. 24:285-294.

Rehm, G.W. 2000. Do we really need a soil test for sulfur? p. 66-69. In Proc. 30th North Central Extension-Industry Soil Fertility Conference. Potash and Phosphate Institute, St. Louis, MO.

Rehm, G.W., S.D. Evans, W.W. Nelson, and G.W. Randall. 1988. Influence of placement of phosphorus and potassium on yield of corn and soybeans. J. Fert. Issues 5:6-13.

Rehm, G.W., and R.C. Sorensen. 1985. Effects of potassium and magnesium applied for corn grown on an irrigated sandy soil. Soil Sci. Soc. Am. J. 49:1446-1450.

Rehm, G.W., R.C. Sorensen, and R.A. Wiese. 1981. Application of phosphorus, potassium, and zinc to corn grown for grain or silage: Early growth and yield. Soil Sci. Soc. Am. J. 45:523-528.

Rehm, G.W., R.C. Sorensen, and R.A. Wiese. 1983. Application of phosphorus, potassium, and zinc to corn grown for grain or silage: Nutrient concentration and uptake. Soil Sci. Soc. Am. J. 47:697-700.

Shapiro, C.A., R.B. Ferguson, G.W. Hergert, A. Dobermann, and C.S. Wortmann. 2003. Fertilizer suggestions for corn. NebGuide G74-174-A. Univ. of Nebraska Coop. Ext. Service, Lincoln.

Sleight, D.M., D.H. Sander, and G.A. Peterson. 1984. Effect of fertilizer phosphorus placement on the availability of phosphorus. Soil Sci. Soc. Am. J. 48:336-340.

USDA-NASS. 2008. United States Department of Agriculture-National Agricultural Statistics Service. Available at http://www.nass.usda.gov (accessed June 2008; verified 4 Feb. 2009).

Verma, S.B., A. Dobermann, K.G. Cassman, D.T. Walters, J.M. Knops, T.J. Arkebauer, A.E. Suyker, G.G. Burba, B. Amos, H. Yang, D. Ginting, K.G. Hubbard, A.A. Gitelson, and E.A. Walter-Shea. 2005. Annual carbon dioxide exchange in irrigated and rainfed maize-based agroecosystems. Agric. For. Meteorol. 131:77-96.

Vyn, T.J., D.M. Galic, and K.J. Janovicek. 2002. Corn response to potassium placement in conservation tillage. Soil Tillage Res. 69:159-169.

Webb, J.R., A.P. Mallarino, and A.M. Blackmer. 1992. Effects of residual and annually applied phosphorus on soil test values and yields of corn and soybean. J. Prod. Agric. 5:148-152.

Witt, C., A. Dobermann, S. Abdulrachman, H.C. Gines, W. Guanghuo, R. Nagarajan, S. Satawatananont, T.T. Son, P.S. Tan, L.V. Tiem, G.C. Simbahan, and D.C. Olk. 1999. Internal nutrient efficiencies of irrigated lowland rice in tropical and subtropical Asia. Field Crops Res. 63:113-138.

Wortmann, C.S., S.A. Xerinda, M. Mamo, and C.A. Shapiro. 2006a. No-till row crop response to starter fertilizer in eastern Nebraska: I. Irrigated and rainfed corn. Agron. J. 98:156-162.

Wortmann, C.S., S.A. Xerinda, and M. Mamo. 2006b. No-till row crop response to starter fertilizer in eastern Nebraska: II. rainfed grain sorghum. Agron. J. 98:187-193. 